\title{
Increasing Citizen Engagement and Participation through eGovernment in Jordan
}

\author{
Raed Kareem Kanaan ${ }^{1} \&$ Ra'ed Masa'deh ${ }^{2}$ \\ ${ }^{1}$ Amman Arab University, Amman, Jordan \\ ${ }^{2}$ Department of Management Information Systems, School of Business, The University of Jordan, Amman, \\ Jordan \\ Correspondence: Raed Kareem Kanaan, Amman Arab University, Amman, Jordan. E-mail: rk@aau.edu.jo
}

Received: May 10, 2018 Accepted: September 20, 2018 Online Published: October 29, 2018

doi:10.5539/mas.v12n11p351 URL: https://doi.org/10.5539/mas.v12n11p351

\begin{abstract}
Supporters of e-Government believe that this technology will be a panacea for enhancing the engagement and participation of citizens in politics and government. However, there is little empirical support for this assertion. Due to the rapid proliferation of e-Government in Jordan there is an impetus to determine how e-Government impacts citizen participation and engagement in politics and government within the country. Using qualitative phenomenological focus group interviews with 40 citizens who utilize e-Government, an effort was made to understand how this technology influences outcomes with regard to participation and engagement with government. The results indicate that those using e-Government were politically active before using the technology and have extensive experience with technology use. E-Government for the politically active serves to extend participation in the process. For individuals that lack technological savvy and/or are not politically active, e-Government alone may not be enough to increase citizen engagement and participation in politics and government.
\end{abstract}

Keywords: citizen engagement, citizen participation, eGovernment, Jordan

\section{Introduction}

Modern governments face a wide range of challenges when it comes to effectively meeting the diverse needs of citizens. The inability of governments to meet the needs has, in some instances lead, to the disenfranchisement of many prompting concern regarding the willingness and ability of citizens to take an active role in political discourse (Wirtz et al., 2014). Initially, scholars called for research concerning exploiting the benefits of crucial electronic systems for job scheduling services (e.g. Karajeh \& Maqableh, 2014; Maqableh \& Karajeh, 2014) among other fields such as on cloud computing (e.g. Tarhini et al., 2017a), e-learning (e.g. Almajali\& Al-Dmour, 2016; Tarhini et al., 2017b), e-services (e.g. Almajali \& Maqableh, 2015; Khwaldeh et al., 2017; Obeidat et al., 2017), online banking (Tarhini et al., 2015),e-learning systems (Almajali et al., 2016), and on e-government (e.g. Alenezi et al., 2017).

In an effort to address some of these challenges e-Government initiatives have been increasingly adopted. As reported by Ifinedo\& Singh (2011) e-Government involves "the utilization of the Internet and World Wide Web for delivering government information and services to citizens and other stakeholders in a country" (166). These authors go on to argue that the purpose of e-Government is to make resources and information more accessible to individuals, increasing citizen engagement in government. Smith (2016) further argues that e-Government has the potential to improve the image of the public sector while increasing citizen trust in government and well as increasing citizen participation in government. Clearly, the use of e-Government holds the potential for substantially altering citizen engagement, participation, and interaction with government at all levels.

\section{Research Background}

\section{1 e-Government Adoption}

The adoption of e-Government by various countries across the globe appears to represent the intersection of a broad range of social, economic and political variables. On one hand, the transactional nature of government has become laborious due to the number of services provided, requiring governments to utilize e-Government as a 
means for interfacing with citizens seeking to complete basic transactions (Nguyen, 2016). This motivation for the development of e-Government has been fueled by a need to increase efficiency in government services while cutting costs (Ziagham, 2011). On the other hand, the adoption of e-Government has been supported as a foundation for increasing citizen engagement and participation in politics and policy creation; a process that is viewed as essential for building a foundation for sustainable social and cultural discourse (Ifinedo \& Singh, 2011).

Even though e-Government has been widely supported across various countries and regions, data indicates that the adoption of this technology platform has not been uniform (Nguyen, 2016). While Bussell (2011) argues that the uneven development of e-Government can be traced to a wide range of social, political, cultural, and economic factors, there is a dearth of empirical research definitively demonstrating which variables universally impact outcomes for e-Government adoption? Nguyen, (2016) further examines the adoption of e Government noting that citizen perceptions of this technology can impact use and continued interest in developing this technology. Specifically, Nguyen (2016) argues that e-Government has, in many instances, failed to deliver promised results, impacting citizen trust in government and the willingness of citizens to access and use these technology platforms. This raises the question of whether the use of this technology platform has increased or decreased citizen engagement and participation in government.

\section{2 e-Government Adoption in Jordan}

e-Government adoption in Jordan has accelerated in recent years. Al-Hujran et al. (2011) note that in Jordan there is a strong desire to build a knowledge-based economy. As a result of this focus, considerable effort and emphasis has been placed on the development of e-Government services (Al-Hujran et al., 2011; Alenezi et al., 2015, 2017). Al-Hujran \& Shahateet (2010) go on to argue that government officials in Jordan have linked the achievement of "good governance" with information and communication technology (ICT). What this suggests is that government officials view technology as an integral component of building effective government services that benefit citizens. Although leaders in Jordan continue to work toward integrating technology as part of a larger plan to improve government, results regarding outcomes including citizen engagementin, e-Government and participation in government are limited. However, existing research on the adoption of e-Government by citizens does provide important insight into factors motivating the decision of citizens to utilize these services.

Data provided by Alomari et al. (2012) indicates that citizen intention to use e-Government in Jordan is shaped by user perceptions regarding trust in the internet, potential advantages for using e-Government, and ease of website use. Similarly Abu-Shanab (2014) found that citizen trust in the internet in general, impacted the decisions of citizens to access and use e Government services. Privacy and security issues were noted to be of particular concern for citizen adoption and use of e Government (Abu-Shanab 2014). Further, Majdalawi et al. (2015) note that citizen adoption and use of e Government in Jordan has been hampered by a lack of awareness among the population regarding services available through the internet. Citizen awareness, trust, and a lack of knowledge regarding internet use were further noted by Al-Hujran \& Shahateet (2010) as impacting citizen adoption of e-Government in Jordan.

Additional insight provided in the empirical research indicates that similar issues regarding e-Government adoption in Jordan have been reported. In particular, Nusir et al. (2012) report that ICT skills represent one of the most pertinent factors influencing e-Government adoption. Perceived ease of technology us, attitudes of citizen, and intentions to use government services have also been noted by Al-Hujran \& Al-dalahmeh, (2011) as having a direct influence on citizen use of e Government in Jordan. Al-Hujran \& Al-dalahmeh (2011) further note the cultural implications shaping e-government use in Jordan. Fidler et al. (2011) also highlight cultural barriers to the adoption of e-Government noting the custom of Wasta and its implications for impacting citizen decision to use this technology.

Although investigations of e-Government in Jordan clearly indicate that there have been numerous studies examining the factors that facilitate and impede citizen use and adoption of this technology, there is a paucity of salient data evaluating the impact of e-Government on those who use this technology. In particular, it is pertinent to consider if e-Government services provide a foundation for engaging citizens to facilitate further interest and participation in government and politics. Understanding the reach of e-Government and its implications for citizen involvement in government is important as supporters of this technology argue that this outcome can be achieved (Ifinedo \& Singh, 2011). Given the current gap in understanding the topic it is imperative to assess how those who regularly utilize e-Government services view their level of participation and interaction with government as a result of utilizing this technology. 


\section{Research Purpose}

Research regarding the implications of e-Government for citizen engagement and participation in politics and government in country of Jordan is still in its infancy. While it is possible to identify a broad range of factors impacting e-Government adoption among citizens, what is not as clear is what occurs when these obstacles are overcome and citizens access and use e-Government services. Do these interactions lead to the desire for citizens to understand government and to take a more active role in politics? Or do e-Government services serve a perfunctory role without actually facilitating user engagement in government activities? The purpose of this qualitative study was to assess the scope and level engagement and participation of Jordanian citizens in politics and government as a result of using e Government tools and services.

\section{Research Methodology}

The methodology selected for use in this investigation was a qualitative phenomenology. A qualitative approach was selected due to the exploratory nature of the topic, the potential for participants to be influenced by a broad range of variables, and the dearth of empirical research on the topic to guide quantitative inquiry into the subject. Qualitative methods are often employed when succinct variables cannot be quantified for investigation (Creswell, 2014). This approach to inquiry offers a foundation for understanding the conditions and context of a specific topic (Creswell, 2014). As noted at the outset of this investigation there is currently a dearth of research examining the impact of e Government on citizens who utilize this technology in Jordan. Quantitative methods to understand the conditions and context of this topic thus justify the choice of this approach in the current research.

A phenomenological framework for investigation was selected due to the emphasis of this methodology on understanding a phenomenon of interest. The focus of the current research aimedto understand the impact of e-Government on engagement and participation for citizens living in Jordan. The influence of e-Government on the behavior of citizens was the primary phenomenon investigated. Phenomenological frameworks typically involve a small number of subjects that are examined to understand patterns and relationships of meaning to the phenomenon under investigation (Creswell, 2014). Data collection for phenomenological investigations typically includes personal or focus group interviews in which an effort is made to collect data based on participant experiences with the phenomenon (Creswell, 2014). Aligning the current research with a phenomenological approach, a focus group was selected for data collection.

\subsection{Data Collection}

A general survey of Internet use was sent to all students, faculty and staff working at a large metropolitan university and adjoining healthcare center to identify individuals with extensive e-Government and internet experience and use. A general internet usage survey was acquired from researchers at the University of Washington and mailed to all known addresses for students, faculty, and staff. A total of 49 individuals reported considerable internet and e-Government service use in the last six months. Each respondent was contacted by phone or email and 40 agreed to participate in the study. Data collection for this investigation employed four focus group interviews of 10 participants each. The focus group interviews were scheduled at a time and place convenient for all focus group members. The focus group interviews were scheduled to last between 45 and 75 minutes. All interviews were videotaped and transcribed within 48 hours of their completion.

\subsection{Data Analysis}

Data analysis for this investigation was undertaken through the use of qualitative data analysis software, Atlas.ti.7. This software provides the ability to identify codes within text data and to uncover relationships between pertinent themes. Information from each of the focus group transcripts was first analyzed to ascertain similarities and differences between the groups with regard to their engagement and participation in government via e-Government services. After which, data from all four transcripts was simultaneously analyzed to acquire a representative picture of how e-Government shapes citizen engagement and participation in government and politics.

\section{Research Results}

The results for this investigation are presented below and include an overview of the pertinent themes noted in each of the focus group interviews followed by a review of connected themes identified across all four of the interviews. The data demonstrates that there are some pertinent factors influencing citizen engagement and participation in government that may not be directly related to e-Government. Understanding these issues may be important for building a better foundation for increasing citizen engagement and participation in government. 
Table 1. Common themes by focus groups

\begin{tabular}{|c|c|c|c|}
\hline Group 1 & Group 2 & Group 3 & Group 4 \\
\hline Politically Active & Extensive Political Action & Politically Active & Politically Active \\
\hline $\begin{array}{l}\text { Comfortable } \\
\text { Technology }\end{array}$ & Technology Adoption & $\begin{array}{l}\text { Comfortable } \\
\text { Technology }\end{array}$ & $\begin{array}{l}\text { Comfortable } \\
\text { Technology }\end{array}$ \\
\hline $\begin{array}{l}\text { High } \\
\text { Adoption }\end{array}$ & At Ease with Technology & $\begin{array}{l}\text { Extensive } \\
\text { Adoption }\end{array}$ & $\begin{array}{l}\text { Peer Support } \\
\text { Technology Use }\end{array}$ \\
\hline $\begin{array}{l}\text { e-Government } \\
\text { Extension }\end{array}$ & $\begin{array}{l}\text { Peer Support } \\
\text { Technology Use }\end{array}$ & $\begin{array}{l}\text { Willingness to Use } \\
\text { e-Government }\end{array}$ & $\begin{array}{l}\text { Extend Involvement } \\
\text { Government }\end{array}$ \\
\hline $\begin{array}{l}\text { e-Government as Tool for } \\
\text { Political Action }\end{array}$ & $\begin{array}{l}\text { Peer Involvement with } \\
\text { Government }\end{array}$ & $\begin{array}{l}\text { Extend Involvement in } \\
\text { Government }\end{array}$ & $\begin{array}{l}\text { Willingness to Use } \\
\text { e-Government }\end{array}$ \\
\hline & $\begin{array}{l}\text { Willingness to Use } \\
\text { e-Government Services }\end{array}$ & $\begin{array}{l}\text { e-Government Supports } \\
\text { Political Activity }\end{array}$ & $\begin{array}{l}\text { e-Government Supports } \\
\text { Political Activity }\end{array}$ \\
\hline
\end{tabular}

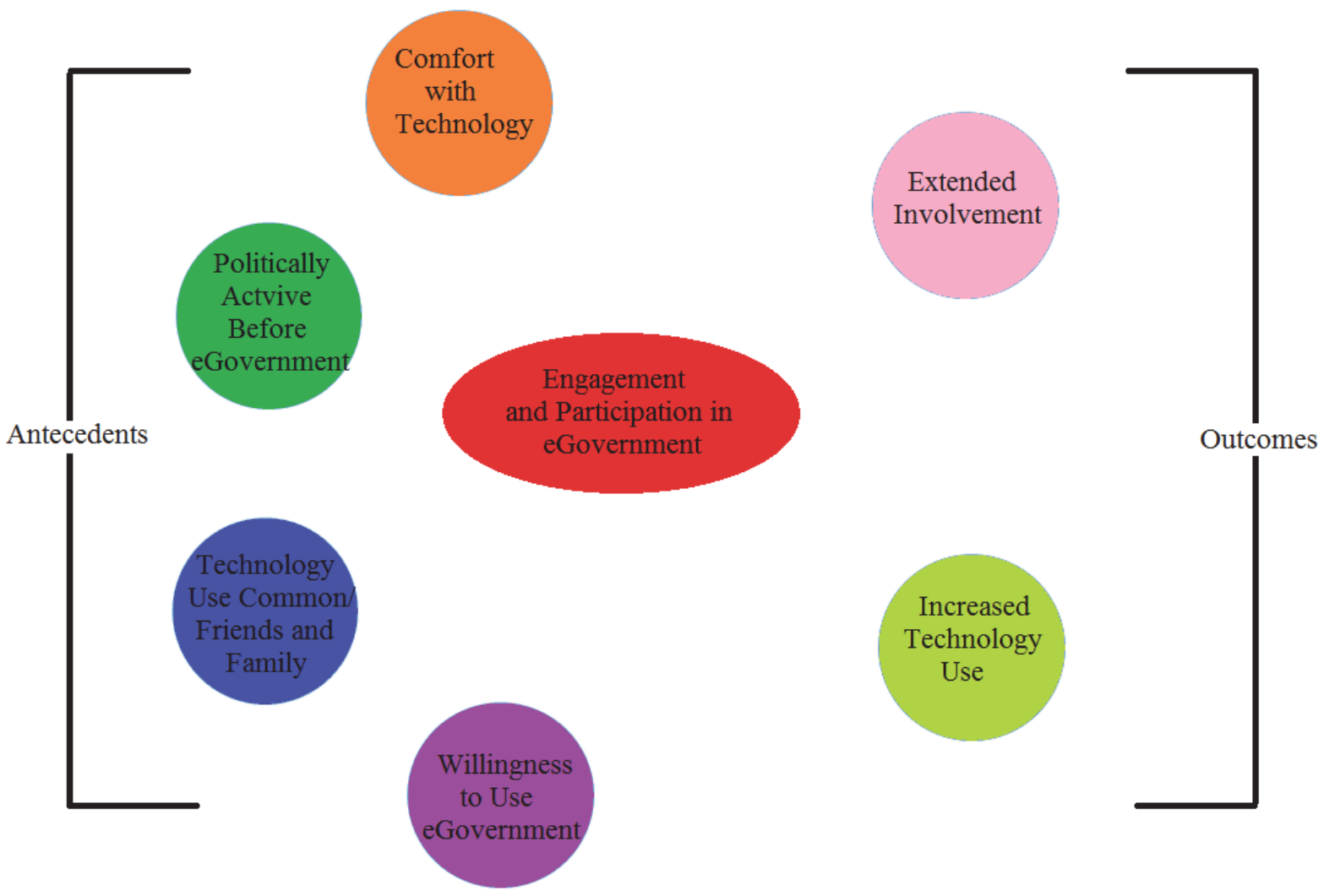

Figure 1. Integration of themes how eGovernment impacts citizens

\section{Conclusion}

One of the key issues highlighted through the data analysis was that citizen engagement and participation in e-Government was supported through antecedents leading to the willingness and ability of the individual to participate this process. The data indicates that comfort with technology, being politically active before e-Government, technology use by family and friends, and willingness to use e-Government serves all played a role in increasing citizen engagement and participation in government and e-Government. The outcomes that resulted from this process included the ability to use e-Government to extend political activity and an increased use of technology in general. Based on this assessment, it is evident that increasing citizen participation and engagement through the use of e-Government can be facilitated through efforts to build citizen involvement with technology and politics simultaneously. 
The results bring to light the importance of addressing political participation in Jordan as a factor influencing citizen use of e Government. Al-Sabeelah et al. (2015) acknowledge that the changing social, economic, and political climate in Jordan may have implications for the participation of citizens in government. In particular, these authors argue that shifts in traditional values and beliefs may serve as the basis for disenfranchising many citizens, disrupting and discouraging participation in the political process. Conceptualizing the intersection of these variables with those that impact individual decision making with regard to using e-Government services is clearly a topic for further consideration.In addition, researchers stressed the point on considering the antecedents and enabling factors of applying electronic services (e.g. Masa'deh, et al., 2008; AlHarrasi \& AL-Lozi, 2015;Kateb, et al., 2015;AlHrassi et al., 2016; Mikkawi \& Al-Lozi, 2017; Abualoush et al., 2018; Masa'deh, et al., 2018), hence, future research is vital to examine theseenablers as toassist stakeholders on their decisions on reaching high levels of e-Government services.

Although proponents of e-Government believe that access to government information via the Internet will facilitate citizen participation in politics and government, the data provided in this investigation suggests that in order to build citizen participation though e-Government simultaneous efforts are needed to build technological competencies and political activism for individuals. Current research regarding political participation by citizens in Jordan does indicate that social and economic changes may be fueling the detachment of citizens from the political sphere further impacting the willingness and desire to engage with government through the use of technology. By building a broader conceptual understanding the confluence of these variables it will be possible to acquire a deeper understanding of the topic. This information could also be utilized as a foundation for increasing citizen willingness and desire to use e-Government as a foundation for extending political action and for becoming more involved in government activities. Clearly, technology alone cannot bridge the divide between citizen engagement and participation in politics and government.

\section{References}

Abualoush, S., Masa'deh, R., Bataineh, K., \& Alrowwad, A. (2018). The role of knowledge management process and intellectual capital as intermediary variables between knowledge management infrastructure and organization performance. Interdisciplinary Journal of Information, Knowledge, and Management, 13, 279-309.

Abu-Shanab, E. (2014). Antecedents of trust in e-government services: An empirical test in Jordan. Transforming Government: People, Process and Policy, 8(4), 480-499.

Alenezi, H., Tarhini, A., \& Masa'deh, R. (2015). Investigating the strategic relationship between information quality and e-government benefits: A literature review. International Review of Social Sciences and Humanities, 9(1), 33-50.

Alenezi, H., Tarhini, A., Alalwan, A., \& Al-Qirim, N. (2017). Factors affecting the adoption of e-government in Kuwait: A qualitative study. Electronic Journal of e-Government, 15(2), 84-102.

AlHarrasi, J., \& AL-Lozi, M. (2015). The role of innovation management and technological innovation on organizational effectiveness. 4th Scientific \& Research Conference on New Trends in Business, Management and Social Sciences (COES\&RJ-TK15/1), Istanbul, Turkey.

AlHrassi, J., Al-Lozi, M., \& Irtaimeh, H. (2016). The impact of management innovation and technological innovation on organizational effectiveness: An empirical study from managerial staff perspective in Sultan Qaboos University. Journal of Social Sciences (COES\&RJ-JSS), 5(3), 309-339.

Al-Hujran, O., \& Al-dalahmeh, M. (2011). The role of national culture on citizen adoption of egovernment web sites. Proceedings of the 11th European Conference on eGovernment, 17-26.

Al-Hujran, O., \& Shahateet, M. (2010). Citizen adoption of egovernment initiatives in developing countries: A case study of Jordan. Proceedings of the European Conference on e-Government, 29-35.

Al-Hujran, O., Al-dalahmeh, M., \& Aloudat, A. (2011). The role of national culture on citizen adoption of egovernment services: An empirical study. Electronic Journal of e-Government, 9(2), 93-106.

Almajali, D., \& Al-Dmour, R. (2016). The role of information technology in motivating students to accept e-learning adoption in universities: A case study in Jordanian universities. Journal of Business \& Management (COES\&RJ-JBM), 4(1), 36-46.

Almajali, D., \& Maqableh, M. (2015). Assessing the digital divide status of the Jordanian telecentre. International Journal of Communications, Network and System Sciences, 8(11), 428-439. 
Almajali, D., Masa'deh, R., \& Al-Lozi, M. (2016). Determinants of the actual use of e-learning systems: An empirical study on Zarqa University in Jordan. Journal of Social Sciences (COES\&RJ-JSS), 5(2), 172-200.

Alomari, M., Woods, P., \& Sandhu, K. (2012). Predictors of e-government adoption in Jordan: Development of an empirical evaluation based on a citizen-centric approach. Information Technology \& People, 25(2), 207-234.

Al-Sabeelah, A. M., Alraggad, F. E. A., \& Abou-Ameerh, O. A. (2015). The dimensions of the citizenship concept among Jordanian university students. International Education Studies, 8(8), 87-102.

Bussell, J. (2011). Explaining cross-national variation in government adoption of new technologies. International Studies Quarterly, 55(1), 267-280.

Creswell, J. W. (2014). Research design: Qualitative, quantitative, and mixed methods approaches. Thousand Oaks, CA: Sage.

Fidler, C. S., Kanaan, R. K., \& Rogerson, S. (2011). Barriers to e-government implementation in Jordan: The role of wasta. International Journal of Technology and Human Interaction, 7(2), 9-20.

Ifinedo, P., \& Singh, M. (2011). Determinants of egovernment maturity in the transition economies of central and Eastern Europe. Electronic Journal of e-Government, 9(2), 166-182.

Karajeh, H., \& Maqableh, M. (2014). Security of cloud computing environment. The 23rd IBIMA Conference on Vision 2020: Sustainable Growth, Economic Development, and Global Competitiveness, USA, 2202-2215.

Kateb, M., Swies, R., Obeidat, B., \& Maqableh, M. (2015). An investigation on the critical factors of information system implementation in Jordanian information technology companies. European Journal of Business and Management, 7(36), 11-28.

Khwaldeh, S., Al-Hadid, I., Masa'deh, R., \& Alrowwad, A. (2017). The association between e-services web portals information quality and ICT competence in the Jordanian universities. Asian Social Science, 13(3), 156-169.

Majdalawi, Y., Almarabeh, T., Mohammad, H., \& Quteshate, W. (2015). E-government strategy and plans in Jordan. Journal of Software Engineering and Applications, 8, 211-223.

Maqableh, M., \& Karajeh, H. (2014). Job scheduling for cloud computing using neural networks. Communications and Network, 6(3), 191-200.

Masa'deh, R., Alrowwad, A., Alkhalafat, F., Obeidat, O., \& Abualoush, S. (2018). The role of corporate social responsibility in enhancing firm performance from the perspective of IT employees in Jordanian banking sector: The mediating effect of transformational leadership. Modern Applied Science, 12(7), 1-26.

Masa'deh, R., Hunaiti, Z., \& Bani Yaseen, A. (2008). An integrative model linking IT-business strategic alignment and firm performance: The mediating role of pursuing innovation and knowledge management strategies. Communications of the International Business Information Management Association (IBIMA) Journal, 180-187.

Mikkawi, B., \& Al-Lozi, M. (2017). The impact of knowledge management infrastructure on academic staff effectiveness: An empirical study at The University of Jordan. Jordan Journal of Business Administration, 13(1), 95-127.

Nguyen, N. A. (2016). A cross-cultural study on egovernment services delivery. Electronic Journal of Information Systems Evaluation, 19(2), 121-134.

Nusir, M., Law, E., \& Hamza Aldabbas, H. (2012). Evaluating the adoption and acceptance of egovernment in developing countries: A case study of Jordan. Proceedings of the European Conference on e-Government, $852-860$

Obeidat, B., Tarhini, A., \& Aqqad, N. (2017). The impact of intellectual capital on innovation via the mediating role of knowledge management: A structural equation modeling approach. International Journal of Knowledge Management Studies, 8(3/4), 273-298.

Smith, D. P. (2016). Egovernment initiatives case study: New models for success. International Journal of Applied Management \& Technology, 15(1), 21-40.

Tarhini, A., Al-Badi, A., Almajali, M., \& Alrabayaah, S. (2017a). Factors influencing employees' intention to use cloud computing. Journal of Management and Strategy, 8(2), 47. 
Tarhini, A., Al-Busaidi, K., Bany Mohammed, A., \& Maqableh, M. (2017b). Factors influencing students' adoption of e-learning: A structural equation modeling approach. Journal of International Education in Business, 10(2), 164-182.

Tarhini, A., Mgbemena, C., \& Trab, MSA. (2015). User adoption of online banking in Nigeria: A qualitative study. Journal of Internet Banking and Commerce, 20(3), 1-8.

Wirtz, B. W., Linda, M., Robert, P., \& Daiser, P. (2014). Measuring egovernment portal management on the local level: Results from a survey of public administration officials. International Public Management Review, 15(2), 1-31.

Ziagham, M. (2011). Barriers to developing egovernment projects in developing countries. Proceedings from the European Conference on e-Government, 363-369.

\section{Copyrights}

Copyright for this article is retained by the author(s), with first publication rights granted to the journal.

This is an open-access article distributed under the terms and conditions of the Creative Commons Attribution license (http://creativecommons.org/licenses/by/4.0/). 